\title{
Review
}

\section{Pentingnya Inovasi Dan Kreatifitas Era Teknologi Digital}

\section{Ahmad Zafrullah Tayibnapis1, Lucia E. Wuryaningsih2, Radita Gora Tn.3}

Di era globalisasi sekarang patut dicermati bahwa konsumen lebih senang dengan pengalaman aktual yang diperoleh dengan caranya sendiri dan nyaman serta praktis melalui internet. Perekonomian Indonesia pada 2019 pasca pemilu mulai membentuk kenormalan baru menyusul berkembangnya digital economy dan leisure economy yang akan menciptakan peluang dan bisnis baru pada 2020. Pebisnis yang survive di era kenormalan baru ini adalah mereka yang mampu menghasilkan produk atau layanan yang more for less, artinya perusahaan harus memberikan more kepada pelanggan dengan less investment (Tayibnapis, Wuryaningsih, dan Gora, 2019).

Bentuk pemasaran yang berkembang saat ini telah menggantikan taktik manipulasi tradisional dengan pendekatan yang lebih asli dan transparan dalam rangka membahas apa yang diinginkan generasi milenial. Pemasaran otentik menurut pandangan Harry Weber (2019) dapat memberikan wawasan untuk menciptakan budaya yang didorong oleh tujuan yang menarik, memotivasi, dan mempertahankan karyawan. Pada era industri 4.0. berbasis teknologi digital tentu membutuhkan sumber daya manusia, yang akan dikelola melaui Talent Management. Talent management menurut Jim Collins dalam Yuni Setyaningsih (2019) merupakan suatu proses untuk mendapatkan, menyumbangkan, dan mempertahankan karyawan yang kompeten dan bekerja tinggi dalam rangka meningkatkan pertumbuhan organisasi.

Ahmad Zafrullah Tayibnapis, Lucia E. Wuryaningsih, dan Gora kemudian melakukan penelitian untuk menganalisis secara keekonomian kondisi eksisting bisnis dan pemasaran di Indonesia era industri 4.0. yang berbasis pada Internet of Things dalam teknologi digital. Hasil penelitian menunjukkan bahwa inovasi yang telah dijalankan baru sebatas pada pengembangan produk atau kemasan, dan bukan perubahan dalam arti menyeluruh; begitu pula penggunaan teknologi belum tergolong hal yang baru. Kebanyakan masih pada tataran menggabungkan hal - hal yang sudah ada dan dimodifikasi, seperti produk - produk minuman, sabun cuci, dan produk produk yang tersaji di super market, hyper market, dan mini market.

Berdasarkan hasil wawancara dan observasi ternyata cara paling efektif untuk mempelajari perilaku konsumen dan kondisi pasar adalah membangun suatu budaya atau menjalankan suatu program dengan melibatkan leaders dan membuka jalur komunikasi yang selebar - lebarnya tanpa proses instan. Semua karyawan senantiasa diberi kebebasan untuk menyalurkan ide dan inovasi sehingga karyawan akan memberikan sesuatu yang terbaik bagi perusahaan, mengingat perilaku konsumen telah mengalami perubahan akibat pengaruh teknologi digital. Konsumen menjadi lebih 
mudah membandingkan antarmerek dan tidak bisa lagi hanya dijadikan target semata. Saat ini konsumen tampak semakin pintar dengan pilihan produk yang semakin banyak, dan bahkan memiliki kekuatan yang semakin tinggi (Tayibnapis, Wuryaningsih, dan Gora., 2019)

Hermawan Kertajaya (2019) menjelaskan bahwa perusahaan yang berada di era teknologi digital perlu memperhatikan lima paradoks, yakni : (1) marketing \& finance, (2) professionalism \& antrepreneurship, (3) productivity \& creativity, (4) kaizen \& innovation, dan (5) management \& leadership. Untuk menjawab ke lima paradoks tersebut dipergunakan the omni brand way guna membesarkan merek di dunia online dan offline sehingga menjadi sebuah kekuatan baru. Dengan demikian diharapkan perusahaan tidak hanya hadir dalam kanal tradisional dan modern saja, tapi juga digital, termasuk memiliki keunikan yang tidak ada pada kompetitor.

Perubahan begitu besar terkait perilaku konsumen yang ada para era teknologi membuat perusahaan membutuhkan marketeer yang memiliki kemampuan techincal skill, soft skill marketing, personality traits, dan empathy. Empati dari seorang marketer ditujukan untuk menangkap insight insight yang relevan dari target pasar, mengambil sari - sari dari hal yang paling mendasar dan paling mengena bagi konsumen. marketeer juga dituntut untuk memiliki kemampuan menganalisis data dan problem solving yang acapkali berdasar pada kreativitas. creative skill dibutuhkan untuk mengontekstualisasikan ide - ide pemasaran ke hal - hal yang relevan dalam berbagai pesan pemasaran (Tayibnapis, Wuryaningsih, dan Gora., 2019).

\section{Daftar Pustaka \\ REFERENSI}

\section{Buku}

Chreswell, John W., 2010, Research Design, Pendekatan Kualitatif, Kuantitatif, dan Mixed, Pustaka Pelajar, Yogyakarta

Dessler, Gary, 2005, Human Resource Development, New Jersey, Prentice Hall, Tenth Edition

Flippo, Edwin B., 1984, Personal Management, Organization, and Strategy, Mason, Thomson, Third Edition

Ulman, Michael M., 2001, E-Business and E-Commerce for Managers, Prentice Hall, USA

Weber, Harry, 2019, Authentic Marketing, John Wiley \& Sons Inc., USA. 


\section{Arktikel Jurnal Internasional}

Tayibnapis., et al. (2019, Oktober 5). Pentingnya Inovasi Dan Kreatifitas Era Teknologi Digital. 532-540.

Tayibnapis, A. Z., et al, 2018, The Development of Digital Economy in Indonesia, International Journey of Management \& Business Studies, Vol. 8, Issue 3, Version July - Sept 2018, India

, 2018, Indonesia's Efforts to Achieve Globally

Competitive Human Resources, International Journal of Humanities and Social Science Invention, Vol. 7, Issue 08. Agustus. 2018, India

, 2018, Peranan Ekonomi Digital dalam Membangun Perekonomian Jawa Timur, Gema Aktualita, Jurnal Ilmiah, Vol. 7, No. 2, Desember 2018, Surabaya

, 2019, Companies in Indonesia in The Vortex of Global Economic Disruption, International Annual Symposium on Management, Proceeding, Tanjung Pinang, Riau Islands, March $4^{\text {rd }}-6^{\text {rd }}, 2019$, Indonesia

\section{Artikel Suratkabar dan Majalah}

Arie M.D., 2019, Mengembangkan Budaya Inovasi, Kompas, Sabtu, 6 Juli 2019, Jakarta

Setyaningsih, Yuni, 2019, Peningkatan Peran Sumber Daya Manusia Untuk Keberlangsungan Bisnis Perusahaan Melalui Manajemen Talenta, Kompas, Sabtu, 13 Juli 2019, Jakarta

Kertajaya, Hermawan, 2019, Ommi Brand : From Wow to Now, Marketeers, July 2019 Issue, Majalah, Jakarta

SWA, 27, XXXIV, 20 Desember 2018 - 19 Januari 2019, Majalah, Jakarta

SWA, XXV, 13 - 26 Juni 2019, Majalah, Jakarta 


\section{Nama Kelompok :}

Ariel Ezra Priscaegiyanti

130216017 / KP A

Rivaldo Yosia Susanti

130216047 / KP A

Yosef Wilyanto

130316030 / KP A

Maria Shinta

130316054 / KP A

Lidya Graciela

130316060 / KP A

Joshua Fernando Santoso

130316075 / KP A

Ivan Wiyono

130316123 / KP A

Flaviana Agustiani Yuniargo

130316333 / KP A

Yohanes Immanuel Ronaldo

130316350 / KP A 